\title{
PERFORMANCE AND WELFARE OF FINISHING PIGS SUBJECTED TO CLIMATE- CONTROLLED ENVIRONMENTS AND SUPPLEMENTARY LIGHTING
}

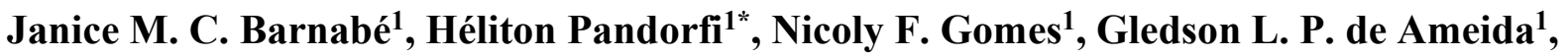 \\ Cristiane Guiselini ${ }^{1}$
}

${ }^{1 *}$ Corresponding author. Federal Rural University of Pernambuco/ Recife - PE, Brazil.
E-mail: hpandorf@hotmail.com | ORCID: https://orcid.org/0000-0002-2037-8639

\section{KEYWORDS}

animal ambience, behavior, thermal comfort, weight gain.

\begin{abstract}
An adequate thermal environment in pig farming facilities is essential to ensure productivity and animal welfare. The objective of this study was to evaluate the behavior and performance of finishing pigs, subjected to climate-controlled environments and supplementary lighting. Twenty-seven pigs (3/4 Duroc, 1/4 Pietrain) were kept in pens with no climate control, pens with forced ventilation and pens with adiabatic evaporative cooling system, associated with $12 \mathrm{~h}$ of natural light, $12 \mathrm{~h}$ of natural light $+4 \mathrm{~h}$ of artificial light and $12 \mathrm{~h}$ of natural light $+6 \mathrm{~h}$ of artificial light. The experimental design was completely randomized, in a $3 \times 3$ factorial arrangement and the means were compared by Tukey test $(\mathrm{p}<0.05)$. Meteorological variables, temperature and relative humidity, were recorded and the zootechnical performance of the animals was evaluated by weight gain, feed intake and feed conversion. Behavioral analysis was performed using the frequency of ingestive and comfort behaviors (exploratory activities and social interactions). Better performance was found for animals subjected to evaporative cooling, and the program with supplementary lighting for 6 hours promoted better feed conversion. Pigs subjected to evaporative cooling showed higher frequency of comfort behaviors and higher frequency of ingestive activity, stimulated by better thermal conditions in the housing.
\end{abstract}

\section{INTRODUCTION}

Brazil is one of the main producers of pork in the world and conquered the market through the high quality standard of the final product, which meets the requirements of even the most demanding consumers of the international market.

Producers are increasingly attentive to the growing demands of the foreign market, with emphasis on production efficiency, sustainability and animal welfare. These technical-economic requirements have become imperative to maintain competitiveness, based on benefitcost ratio, when compared to conventional production systems, avoiding misguided investments.

The welfare condition of production animals is fundamental from the perspective of pig performance, because it allows the expression of specific behaviors of the species, which influences better physical and psychological development of the animal, with a positive effect on the quality of the final product (Maia et al., 2013; Foppa et al., 2014).
There is a close relationship between thermal comfort and animal welfare, both of which directly suffer from the interference of the environment in intensive rearing, which causes difficulty in the maintenance of energy balance inside the facilities and in the expression of natural behaviors, affecting the productive and reproductive performance of pigs.

This factor is extremely relevant in the production systems in Brazil, since the largest part of the country faces high temperatures in most of the year. Thus, it is fundamental to implement new technologies in the facilities that meet the physiological and social demands of animals. Therefore, the most common is that attention is directed to the implementation of climate control systems. However, the behavioral response of pigs is usually disregarded at the time of choosing and adjusting the type of climate control system, which may depreciate the zootechnical indices.

Another management alternative that has been studied aiming to improve pig productivity is the use of supplementary lighting programs, whose principle is to encourage food intake at night and, therefore, compensate

${ }^{1}$ Federal Rural University of Pernambuco/ Recife - PE, Brazil.

Area Editor: Danilo Florentino Pereira

Received in: 11-26-2018

Accepted in: 4-13-2020 
for the deficit of consumption at times of higher temperatures (Amaral et al., 2014; Ferreira et al., 2016).

Thus, the objective of this study was to evaluate the behavior and performance of pigs in the finishing phase, housed in pens with climate control and supplementary lighting programs.

\section{MATERIAL AND METHODS}

The study was carried out in the Swine Experimentation Bioterium of the Serra Talhada Academic Unit (BES - UAST) of the Federal Rural University of Pernambuco, municipality of Serra Talhada, Sertão Mesoregion and Pajeú Microregion, State of Pernambuco, Brazil $\left(07.98^{\circ} \mathrm{S}\right.$ latitude, $38.28^{\circ} \mathrm{W}$ longitude and altitude of $444 \mathrm{~m})$. According to Köppen's climate classification, the climate of the region is characterized as BShw', hot and dry semi-arid climate. The annual averages of rainfall, temperature and relative humidity in the region are 642.1 $\mathrm{mm}, 24.8{ }^{\circ} \mathrm{C}$ and $62.5 \%$, respectively (Silva et al., 2015).

The research was conducted from October to November 2017, approved by the CEUA/UFRPE (Ethics Committee on the Use of Animals), under protocol no. 23082.021090/2016-81.

Twenty-seven pigs (3/4 Duroc, 1/4 Pietrain) in the finishing phase were used. The animals were housed in an experimental masonry shed composed of 30 pens, with central corridor covered with 6-mm-thick fiber cement roofing sheets. The pens were covered with ceramic tiles with one pitch, $15^{\circ}$ slope and concrete floor. Each pen was $6.0 \mathrm{~m}^{2}$, with ceiling height of $2.2 \mathrm{~m}$ and $1.1-\mathrm{m}$ - high walls, equipped with a semi-automatic feeder and a nipple drinker. The animals were randomly distributed in nine pens, three animals per pen $\left(2 \mathrm{~m}^{2}\right.$ animal $\left.{ }^{-1}\right)$.

The variation factors studied were pens with no climate control (NC), pens with forced ventilation (FV) and pens with adiabatic evaporative cooling system (EC), associated with $12 \mathrm{~h}$ of natural light (L12), $12 \mathrm{~h}$ of natural light $+4 \mathrm{~h}$ of artificial light (L16) and $12 \mathrm{~h}$ of natural light $+6 \mathrm{~h}$ of artificial light (L18). The climate control system was triggered every day from $8 \mathrm{~h} 00$ to $18 \mathrm{~h} 00$. The supplementary lighting programs consisted of different activation times, from $18 \mathrm{~h} 00$ to $22 \mathrm{~h} 00$ (L16) and from $23 \mathrm{~h} 00$ to $05 \mathrm{~h} 00$ (L18). The climate control and lighting systems were activated by means of properly programmed analog timers.

Climate control by forced ventilation was performed by axial fans with flow of $1200 \mathrm{~m}^{3} \mathrm{~h}^{-1}$ at 1,780 RPM and diameter of 11 ", which provided airflow at an average speed of $3.4 \mathrm{~m} \mathrm{~s}^{-1}$.
The adiabatic evaporative cooling system consisted of evaporative air conditioners, which promote mist formation through the centrifugal effect of a central disc with an average flow rate of $7 \mathrm{~L} \mathrm{~h}^{-1}$, using independent motors with blade rotation of 1,750 RPM and the central disc rotation of 3,450 RPM, with average airflow velocity of $2.5 \mathrm{~m} \mathrm{~s}^{-1}$.

The supplementary lighting system was composed of soft/warm 15-W compact fluorescent lamps, installed in the geometric center of the pens at $1.83 \mathrm{~m}$ height from the floor. The illuminance available to the animals subjected to light supplementation was $40 \mathrm{~lx}$.

The nutritional management of the animals followed the concept of ideal protein, by development phase, meeting the nutritional requirements described by Rostagno (2017). Feed was provided at will, being distributed twice a day (morning and afternoon).

The meteorological variables dry bulb temperature $\left(\mathrm{Tdb} ;{ }^{\circ} \mathrm{C}\right)$ and relative humidity $(\mathrm{RH} ; \%)$ were recorded every hour, inside the pens and in the external environment, by HOBO U12-12 dataloggers (Onset Computer Corporation Bourne, MA, USA). The dataloggers were installed in the geometric center of each pen at $1.0 \mathrm{~m}$ height from the floor and in the external environment inside a weather shelter at $1.5 \mathrm{~m}$ height from the ground.

The performance of the animals was evaluated by feed intake (FI; $\mathrm{kg}$ ), feed conversion ( $\mathrm{FC} ; \mathrm{kg} \mathrm{kg}^{-1}$ ) and weight gain (WG; $\mathrm{kg}$ ). Feed intake was quantified from the sum of daytime feed intake (DFI; kg) and nighttime feed intake (NFI; kg). For this, the feeders were supplied in the morning and afternoon, and the surplus of feed from the previous supply was weighed on an electronic scale before each new supply. For WG determination, the animals were weighed every week on an LD1050 electronic scale, coupled to a containment structure.

The behavior of the animals was evaluated by means of images recorded by VMD S3020 IR color cameras, with infrared and $3.6 \mathrm{~mm}$ lens, installed inside the pens.

The records were performed weekly, for 24 uninterrupted hours, along the entire experiment. The behaviors expressed by the animals were recorded and quantified considering the behaviors of the three animals of each pen, in the period of 24 hours, and the observations were performed for $10 \mathrm{~min}$ at each hourly interval.

Behavioral variables were counted and identified using an ethogram based on Massari et al. (2015) and Pandorfi \& Silva (2005), as described in Table 1, quantifying the frequency and percentage of observation time of the animals in each behavior listed in their respective treatments. 
TABLE 1. Behavioral ethogram for pigs at finishing phase

\begin{tabular}{|c|c|c|}
\hline Behavior & & Description \\
\hline \multicolumn{3}{|c|}{ Posture } \\
\hline Lying & $\begin{array}{l}\text { ventral position } \\
\text { lateral position }\end{array}$ & $\begin{array}{l}\text { belly resting on the floor with all legs under the body. } \\
\text { resting on its side with all legs horizontally outstretched. }\end{array}$ \\
\hline \multicolumn{3}{|c|}{ Activity } \\
\hline Access to feeder & & mouth in the feeder. \\
\hline \multirow[t]{2}{*}{ Drinking } & & mouth in the drinker. \\
\hline & smelling the floor & smelling the floor making circular movements. \\
\hline \multirow{4}{*}{ Comfort } & sniffing & sniffing the floor, exploring the environment. \\
\hline & nibbling & $\begin{array}{l}\text { making short bite movements, while touching another animal } \\
\text { with the mouth. }\end{array}$ \\
\hline & smelling & $\begin{array}{l}\text { smelling another animal, making circular movements and } \\
\text { sniffing along its body. }\end{array}$ \\
\hline & licking & licking another animal, touching it with the tongue. \\
\hline
\end{tabular}

According to the ethogram, the "lying" posture was considered from the sum of the positions (lying in the ventral and lateral positions), and the "comfort behavior" was represented by the sum of exploratory activities (smelling the floor and sniffing) and social interactions (nibbling, smelling and licking).

The experimental design was completely randomized, in a $3 \times 3$ factorial arrangement, in which the 27 animals used were randomly distributed in the nine pens, with three animals per pen. Statistical analysis of the data was performed using the program Statistical Analysis System (SAS, 2007) and the means were compared by Tukey test $(\mathrm{p}<0.05)$.

The behavioral analysis of the animals was determined by the frequency and percentage of time spent in each behavior and its probability of occurrence by the Chi-square test $\left(\mathrm{X}^{2}\right)$.

\section{RESULTS AND DISCUSSION}

Descriptive analysis of environmental data dry bulb temperature $\left(\mathrm{Tdb} ;{ }^{\circ} \mathrm{C}\right)$ and relative humidity $(\mathrm{RH} ; \%)$ in the external environment (EXT) and inside the pens with no climate control (NC), with forced ventilation (FV) and with evaporative cooling (EC), measured along the experimental period, show that $75 \%$ of the Tdb data recorded in the external environment were between 19.3 and $30^{\circ} \mathrm{C}$, and the mean values for $\mathrm{Tdb}$ and $\mathrm{RH}$ were on the order of $25.9^{\circ} \mathrm{C}$ and $64.5 \%$, respectively (Figure 1 ).
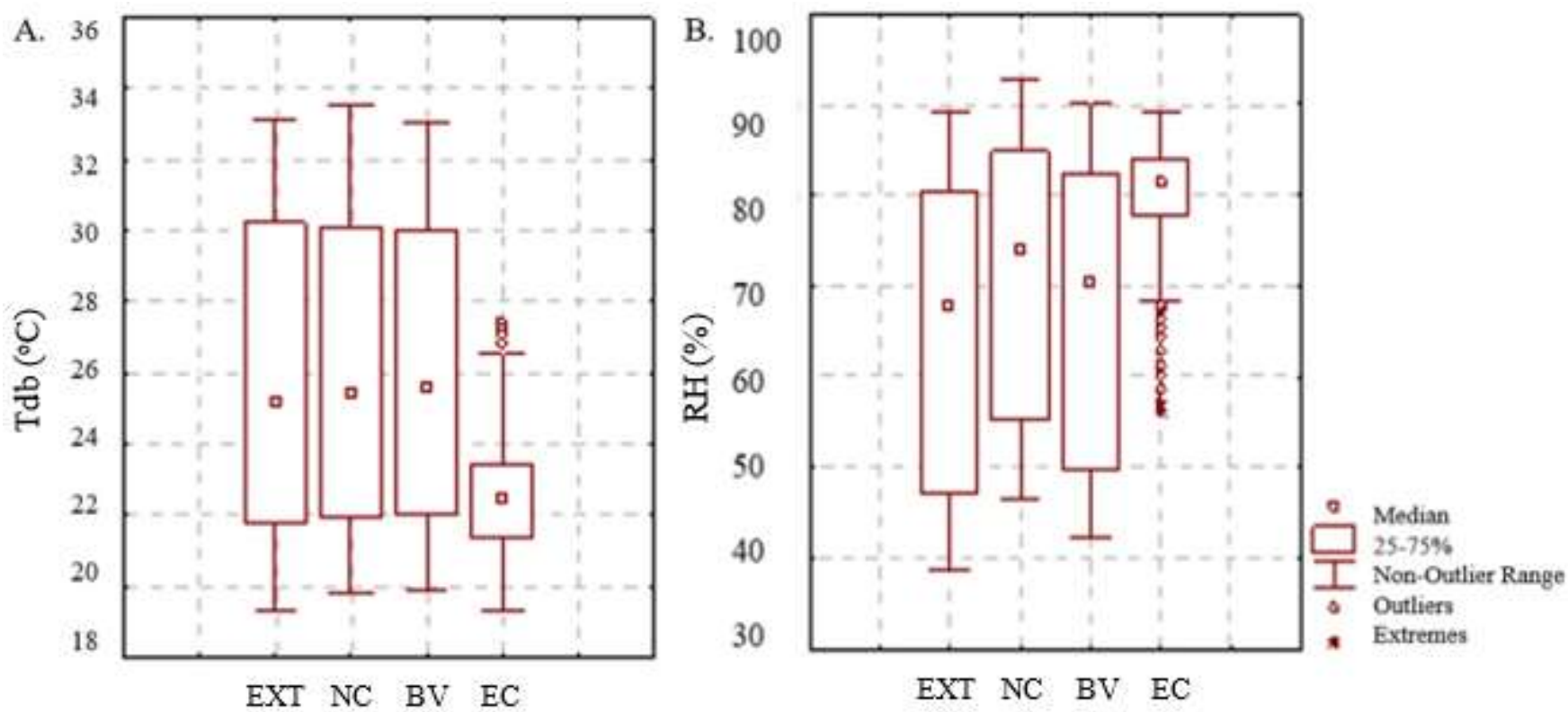

FIGURE 1. Variation of dry bulb temperature $\left(\mathrm{Tdb} ;{ }^{\circ} \mathrm{C}\right)(\mathrm{A})$ and relative humidity $(\mathrm{B})$ in the external environment $(\mathrm{EXT})$ and inside the pens with no climate control (NC), with forced ventilation (BV) and with evaporative cooling (EC).

In pens with no climate control and with forced ventilation, the minimum and maximum $\mathrm{Tdb}$ values recorded were 19.8 and $33.5{ }^{\circ} \mathrm{C}$, respectively, and the temperature remained approximately between 19.8 and $30{ }^{\circ} \mathrm{C}$ in $75 \%$ of the period. The mean $\mathrm{Tdb}$ for both was $26.7{ }^{\circ} \mathrm{C}$ (Figure $1 \mathrm{~A})$, and the mean $\mathrm{RH}$ was $70.8 \%$ for the pens with no climate control and $67.1 \%$ for pens with forced ventilation (Figure 1B).

Figure 1A shows that $\mathrm{Tdb}$ in pens with evaporative cooling did not exceed $27.4{ }^{\circ} \mathrm{C}$ and the mean of the period was $22.6{ }^{\circ} \mathrm{C}$. The mean value of $\mathrm{RH}$ was $79.5 \%$, and $75 \%$ of the records were between 68 and $82 \%$. Therefore, the 
evaporative cooling system ensured better thermal comfort for the animals, considering the upper critical limit of $27^{\circ} \mathrm{C}$ and tolerable limits from 40 to $70 \%$, for temperature and relative humidity, respectively (Leal \& Nããs, 1992).
Weight gain (WG) did not show significant interaction for the lighting factor, but was significantly affected by climate control $(\mathrm{p}<0.05)$, while feed intake $(\mathrm{FI})$ and feed conversion (AC) showed interactions between the two factors tested $(\mathrm{p}<0.05)$ (Table 2$)$.

TABLE 2. Mean values of the variables weight gain $(\mathrm{kg})$, feed intake $(\mathrm{kg})$ and feed conversion $\left(\mathrm{kg} \mathrm{kg}^{-1}\right)$.

\begin{tabular}{|c|c|c|c|c|c|}
\hline \multirow[b]{2}{*}{ Variables } & \multirow{2}{*}{\multicolumn{2}{|c|}{ Climate control }} & \multicolumn{3}{|c|}{ Lighting } \\
\hline & & & L12 & L16 & L18 \\
\hline & $\mathrm{NC}$ & $39.5 \mathrm{c}$ & & & \\
\hline \multirow[t]{2}{*}{ Weight gain (kg) } & BV & $44.0 \mathrm{~b}$ & ns & ns & ns \\
\hline & $\mathrm{EC}$ & $50.5 \mathrm{a}$ & & & \\
\hline \multirow{3}{*}{ Feed intake $(\mathrm{kg})$} & $\mathrm{NC}$ & & $114.3 \mathrm{~b} \mathrm{~A}$ & $95.3 \mathrm{c} \mathrm{C}$ & $107.3 \mathrm{~b} \mathrm{~B}$ \\
\hline & BV & - & 139.5 a A & $120.3 \mathrm{~b} \mathrm{C}$ & $128.1 \mathrm{a} \mathrm{B}$ \\
\hline & $\mathrm{EC}$ & & 140.7 a A & 125.9 a B & $104.4 \mathrm{~b} \mathrm{C}$ \\
\hline \multirow{3}{*}{ Feed conversion $\left(\mathrm{kg} \mathrm{kg}^{-1}\right)$} & $\mathrm{NC}$ & & $2.7 \mathrm{~b} \mathrm{~A}$ & $2.5 \mathrm{~b} \mathrm{~B}$ & $2.8 \mathrm{a} \mathrm{A}$ \\
\hline & BV & - & $3.0 \mathrm{a} \mathrm{A}$ & 2.7 a B & 2.9 a A \\
\hline & $\mathrm{EC}$ & & $2.5 \mathrm{~b} \mathrm{~A}$ & $2.5 \mathrm{~b} \mathrm{~A}$ & $2.1 \mathrm{~b} \mathrm{~B}$ \\
\hline
\end{tabular}

Means followed by equal letters, lowercase in the column and uppercase in the row, do not differ statistically by Tukey test at $5 \%$ probability. ns - Not significant.

For the WG variable, all means differed $(\mathrm{p}<0.05)$, and the highest value was recorded in animals exposed to evaporative cooling, followed by those receiving forced ventilation. There was a reduction of $21.8 \%$ in the WG of animals housed in the pens with no climate control, compared to those kept under evaporative cooling (Table 2). These results corroborate those of Santos et al. (2012), who also verified greater weight gain in pigs subjected to cooling compared to the treatment with natural ventilation. Lower weight gain in pigs subjected to high temperatures was also observed by Santos et al. (2018), when housing pigs in pens with and without access to water.

The highest feed intake (FI) was observed in animals subjected to evaporative cooling, with 12 hours of light, but with no significant effect on the average consumption of animals housed in the pens with forced ventilation. The lowest FI was observed in the animals housed in pens with no climate control. A similar effect was found by Berton et al. (2015) when comparing pigs within the comfort zone and under thermal stress.

The comparison of lighting programs associated with climate control systems showed a difference between them $(p<0.05)$; however, it is possible that higher feed intake was not stimulated by the increase in lighting time (Table 2). Animals subjected to the lighting program with 16 hours of light had higher feed intake than those exposed to 18 hours of light.

The lowest mean of FI was found among the animals subjected to the pens with no climate control and 16 hours of light, which differed $(\mathrm{p}<0.05)$ from those in pens with forced ventilation and evaporative cooling. Regarding the effect of lighting, all means differed from each other $(p<0.05)$, but the result of the comparison between 16 and 18 hours of light were contrary to that observed in the pen with evaporative cooling (Table 2).
These results are consistent with those obtained by Amaral et al. (2014), who used lighting programs for finishing pigs. The same response was achieved in the studies conducted by Reiners et al. (2010) and Sousa Júnior et al. (2011) for pigs at other phases of rearing.

The means of feed conversion (FC) among animals exposed to climate control factors within each lighting program showed that those exposed to 12 and 16 hours of light had worse conversion when housed in pens with forced ventilation, which differed $(\mathrm{p}<0.05)$ from the others. However, for animals exposed to 18 hours of light, there was difference $(\mathrm{p}<0.05)$ between those housed in pens with cooling and the others, and also the worst means were attributed to animals in pens with no climate control and with forced ventilation (Table 2).

According to the effect of lighting, it is observed that the best mean of FC occurred in animals exposed to climate control by evaporative cooling and 18 hours of light, which differed $(\mathrm{p}<0.05)$ from those subjected to the programs of 12 and 16 hours of light. Therefore, the prolongation of lighting, when associated with evaporative cooling, possibly favored the FC of the animals.

Martelli et al. (2005) found that the 14-hour lighting period was less favorable to feed conversion than the 8-hour lighting period. On the other hand, Amaral et al. (2014) and Ferreira et al. (2016) did not find better FC when prolonging the lighting period for pigs.

The performance analysis indicated that the climate control system by evaporative cooling promoted the best zootechnical indices. As for the use of supplementary lighting, there was no effect on WG, while for FI, the best means were obtained without light supplementation and the best FC was observed in animals subjected to the lighting program with 18 hours of light.

Daytime feed intake (DFI; kg) and nighttime feed intake (NFI; kg) showed significant interactions for the variation factors analyzed, as presented in Table 3. 
TABLE 3. Mean values of daytime feed intake $(\mathrm{kg})$ and nighttime feed intake $(\mathrm{kg})$.

\begin{tabular}{|c|c|c|c|c|}
\hline \multirow[b]{2}{*}{ Variables } & \multirow[b]{2}{*}{ Climate control } & \multicolumn{3}{|c|}{ Lighting } \\
\hline & & L12 & L16 & L18 \\
\hline \multirow{3}{*}{ Daytime feed intake $(\mathrm{kg})$} & $\mathrm{NC}$ & $47.4 \mathrm{~b} \mathrm{~B}$ & 40.6 a $\mathrm{C}$ & $51.8 \mathrm{~b} \mathrm{~A}$ \\
\hline & BV & $67.6 \mathrm{a} \mathrm{A}$ & 57.7 a $\mathrm{C}$ & $62.5 \mathrm{a} \mathrm{B}$ \\
\hline & $\mathrm{EC}$ & 69.7 a A & $60.4 \mathrm{a} \mathrm{B}$ & $51.4 \mathrm{~b} \mathrm{C}$ \\
\hline \multirow{3}{*}{ Nighttime feed intake $(\mathrm{kg})$} & $\mathrm{NC}$ & $64.2 \mathrm{~b} \mathrm{~A}$ & $48.4 \mathrm{~b} \mathrm{C}$ & $55.6 \mathrm{~b} \mathrm{~B}$ \\
\hline & $\mathrm{BV}$ & 76.0 a A & 65.0 a B & 74.4 a A \\
\hline & $\mathrm{EC}$ & $76.1 \mathrm{a} \mathrm{A}$ & $67.0 \mathrm{a} \mathrm{B}$ & $52.9 \mathrm{~b} \mathrm{C}$ \\
\hline
\end{tabular}

Means followed by equal letters, lowercase in the column and uppercase in the row, do not differ statistically by Tukey test at $5 \%$ probability level.

The variation factors showed significant effect of all combinations on daytime and nighttime feed intakes. Table 3 shows that the animals with the highest feed intake were those subjected to evaporative cooling with 12 hours of light, but these animals differed $(p<0.05)$ only from those under no climate control for both DFI and NFI. The ventilation system with 18 hours of light differed $(p<0.05)$ from the other treatments within the lighting factor, standing out with the highest means of daytime and nighttime feed intakes.

The behavioral analysis identified that, during the day, the animals remained "lying" for a longer period, from 9 to $15 \mathrm{~h} 00$, which correspond to the times of highest temperatures (Figure 2A; B; C).

Pens with no climate control
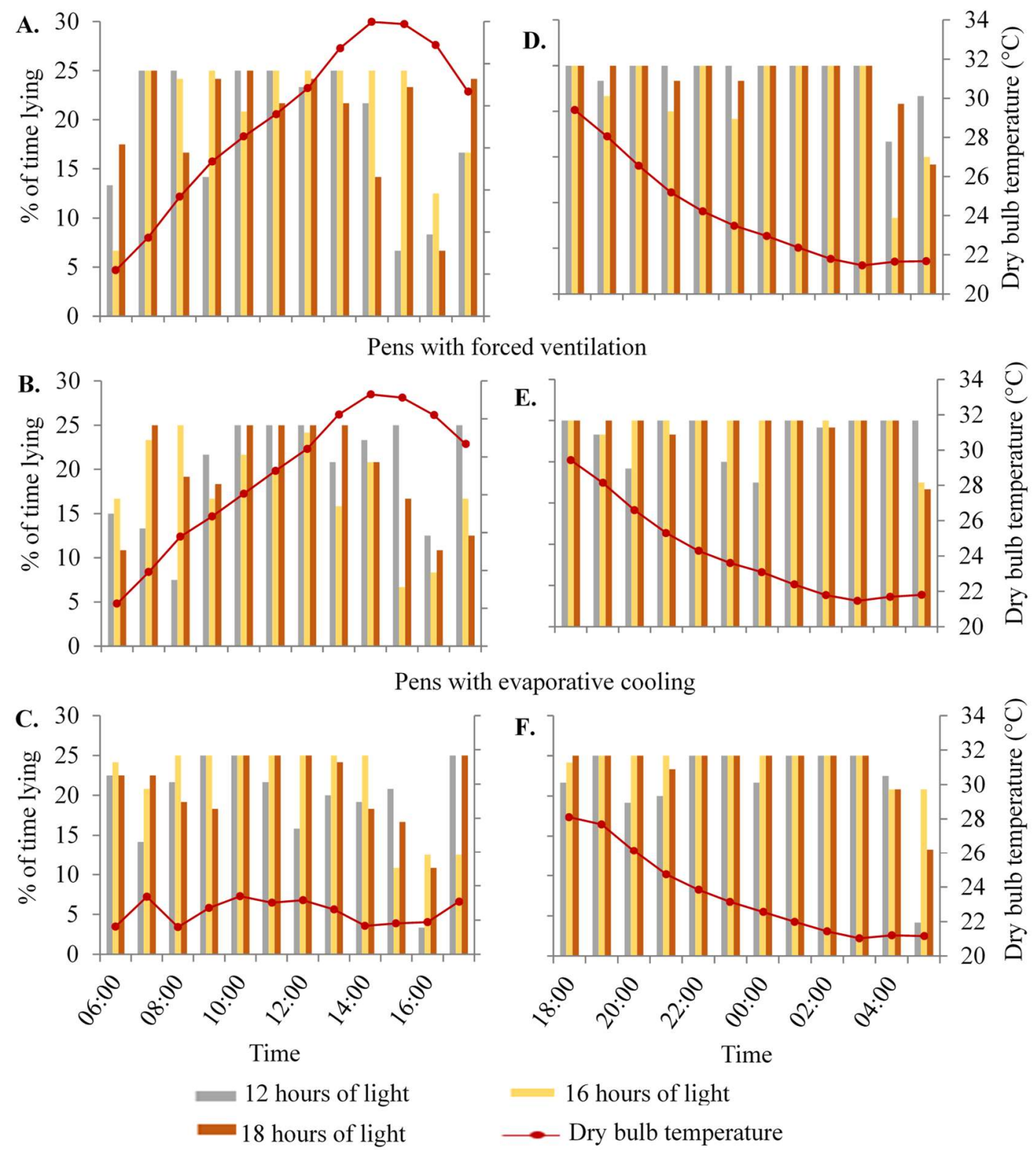

FIGURE 2. Percentage of time "lying" in the daytime (A, B and C) and nighttime (D, E and F) periods in pens with no climate control, with forced ventilation and with evaporative cooling, associated with the lighting programs of 12,16 and 18 hours of light $(\mathrm{p}<0.01)$. 
The animals housed in pens with no climate control and with evaporative cooling were the ones with the highest frequency of "lying" behavior. When housed in environments with no climate control this behavior can be justified by thermal discomfort, so the animals assumed a posture that facilitated thermal exchanges through the contact with the pen floor. This relationship has also been evidenced by Massari et al. (2015) and Kiefer et al. (2010).

As for the animals kept in the pen with evaporative cooling, the fact that they spent more time lying down is justified by the higher body weight (Table 2), which hampers their locomotion (Figure 2).

At night, the animals in the pen with no climate control and under 12 hours of light (Figure 2D) had higher frequency in the "lying" position and the animals that remained shorter in this position were those exposed to 16 hours of light. Amaral et al. (2014) also observed that pigs that received supplementary lighting were more active at night, when compared to those that did not.

The frequency of the "eating" activity during the day, as can be seen in Figure 3A, B and C, shows that the animals had more access to the feeder in the late afternoon. Animals housed in pens with no climate control (Figure 3A) did not access the feeders in the interval from 11 to $14 \mathrm{~h} 00$, which must be related to the high temperature in the facilities. This response is in accordance with the data presented in Table 3, in which the lowest means of FI were found in animals kept in pens with no climate control and under 12 and 16 hours of light. Paiano et al. (2007) also found a reduction in consumption at the times of more critical temperatures, for pigs in the growth and finishing phases.

The animals housed in pens with forced ventilation (Figure 3B) had a higher frequency of access to the feeder, concomitantly with higher feed intake (Table 2).
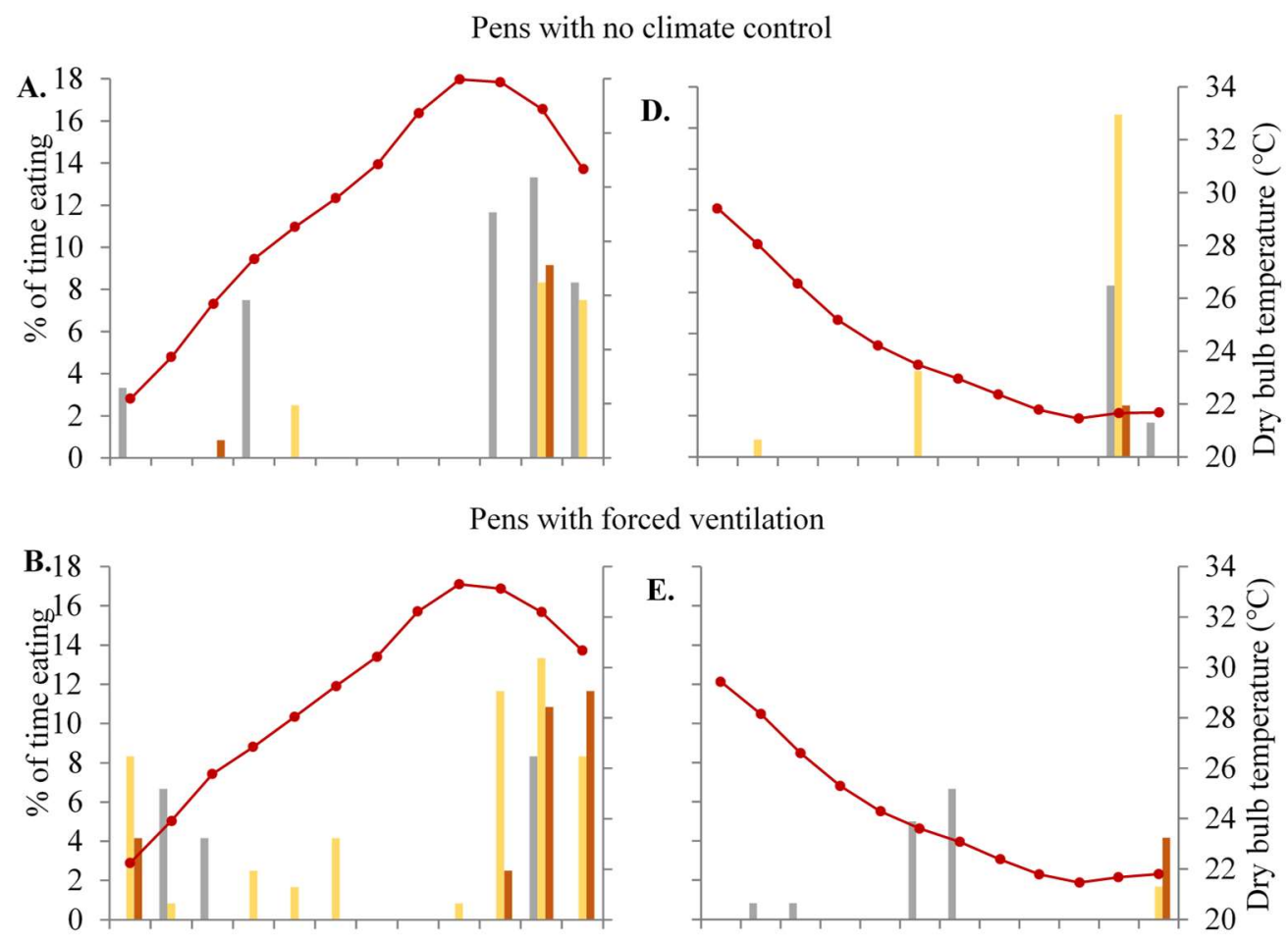

Pens with evaporative cooling
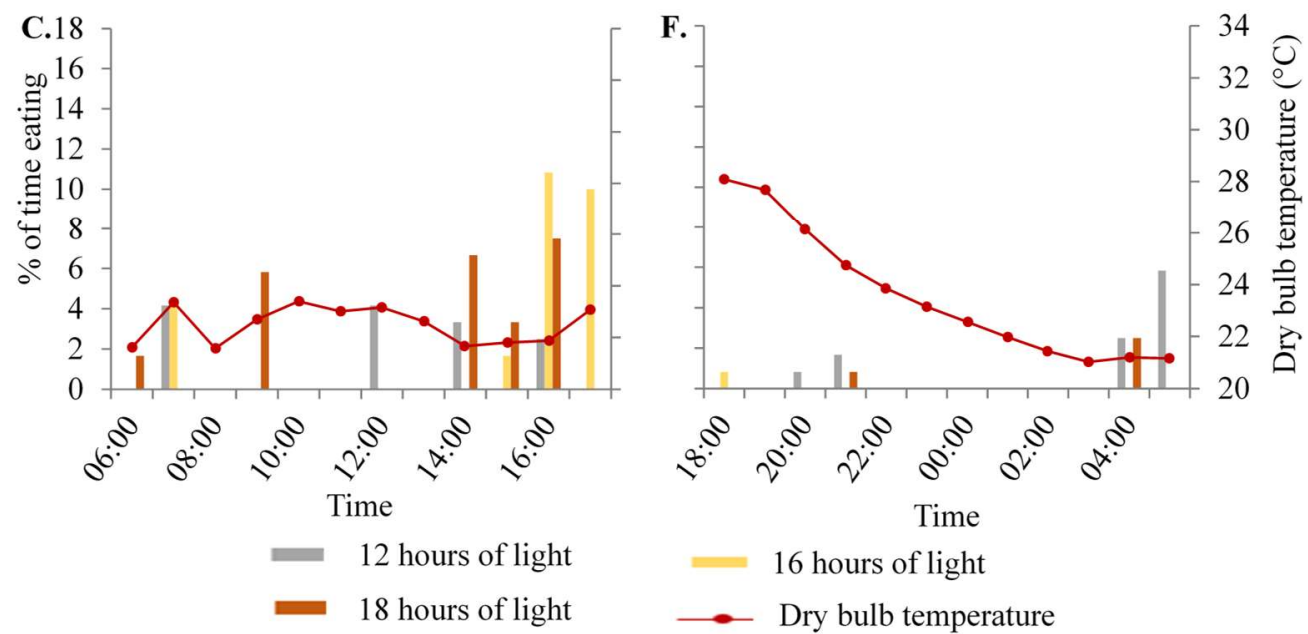

FIGURE 3. Percentage of time "eating" in the daytime (A, B and C) and nighttime (D, E and F) periods in pens with no climate control, with forced ventilation and with evaporative cooling, associated with the lighting programs of 12,16 and 18 hours of light $(\mathrm{p}<0.01)$. 
For animals subjected to pens with evaporative cooling, the frequency of access to the feeder occurred throughout the day (Figure 3C), but the total time spent on visits to the feeders was lower than in the other treatments. Table 3 shows that the total feed intake of animals in pens with evaporative cooling was lower $(3.35 \%)$ than that for animals kept in pens with forced ventilation.

At night, there were few records of the "eating" activity (Figure 3D, E, F), which indicates that the use of supplementary lighting programs did not stimulate this behavior. Although no significant difference was reported between daytime and nighttime intake, numerically the highest consumption occurred during the night time.

Table 3 shows that the highest average feed intake was observed in animals that did not receive supplementary lighting, a result that is consistent with the frequency presented in Figure 3E and F. However, it contradicts the results obtained by Amaral et al. (2014), who verified a higher frequency in the "eating" activity, when exposed to supplementary lighting. Likewise, Ferreira et al. (2016) observed that the animals exposed to the 19-hour lighting program had a higher frequency in the activity, but these authors state that higher feed intake was not observed.

The analysis of the frequency of the animals at the drinker showed that it was higher for those housed in pens with forced ventilation, both during the day and during the night, and the treatment with 12 hours of light was the one that most stood out (Figure 4E), which does not agree with the results reported by Amaral et al. (2014), who observed longer time in the "drinking" activity in animals under periods of prolonged lighting. However, Ferreira et al. (2015) reported that growing pigs spent more time on visits to the drinker when exposed to the longest lighting period, but without differing statistically.

Pens with no climate control
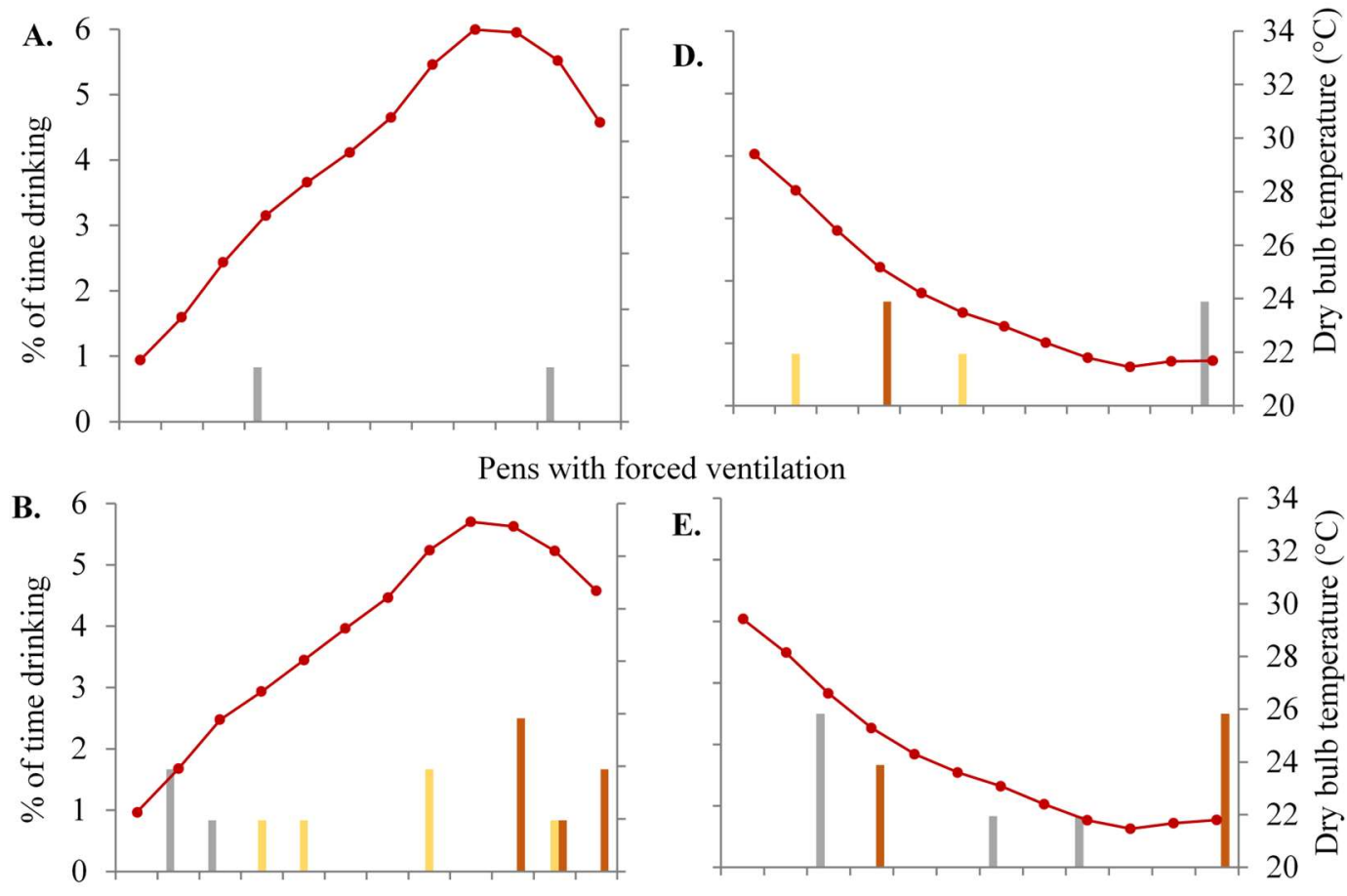

Pens with evaporative cooling
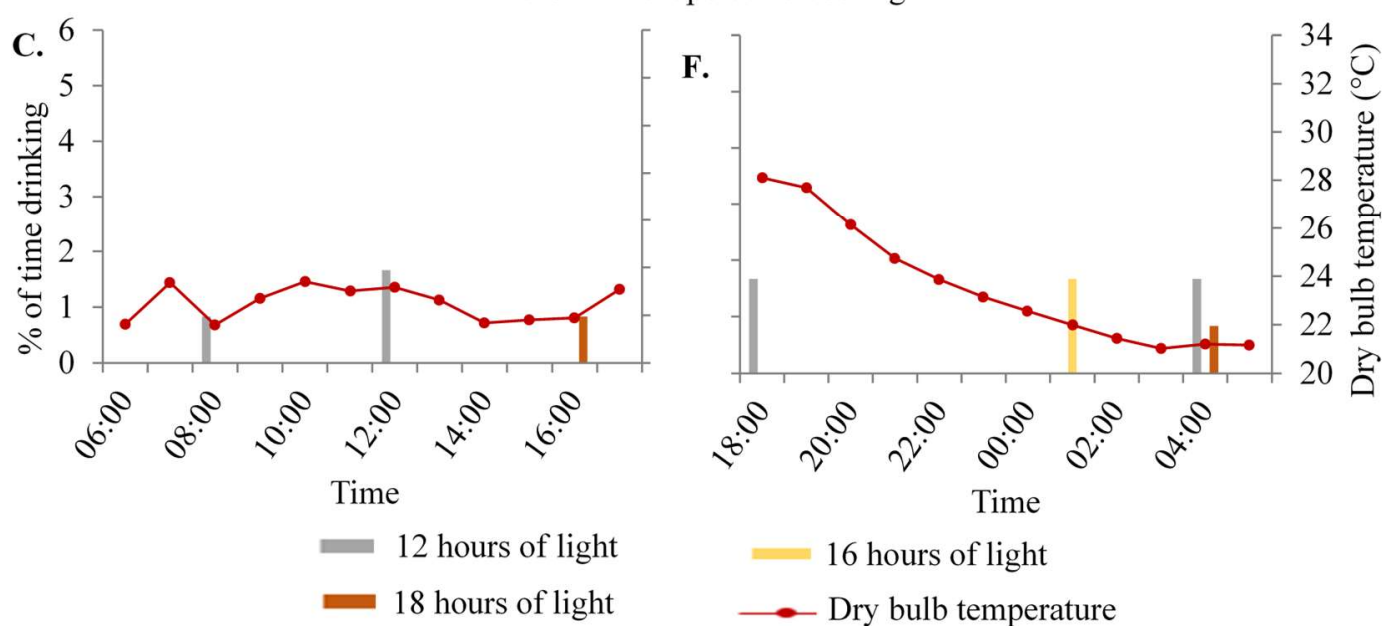

16 hours of light

Dry bulb temperature

FIGURE 4. Percentage of time "drinking" in the daytime (A, B and C) and nighttime (D, E and F) periods in pens with no climate control, with forced ventilation and with evaporative cooling, associated with the lighting programs of 12,16 and 18 hours of light $(\mathrm{p}<0.01)$. 
Animals housed in pens with no climate control and with evaporative cooling spent more time on visits to the drinker at night (Figure 4D and 4F). According to Padilha et al. (2013), the highest water consumption occurs at the times of dry food consumption, which is consistent with the data presented in Table 3, showing that the animals consumed more food at night.
Figure $5 \mathrm{~A}, \mathrm{~B}$ and $\mathrm{C}$ shows that throughout the day the animals that performed activities related to "comfort" for longer were those housed in pens with forced ventilation, corroborating the results found by Carvalho et al. (2004), who observed better social behavior in pigs housed in climate-controlled environments with ventilation and nebulization.

Pens with no climate control

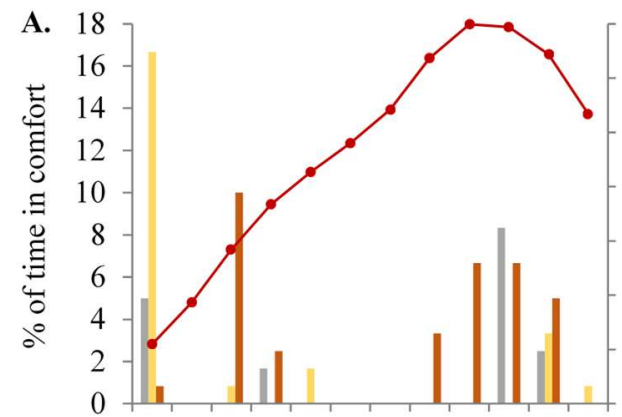

D.

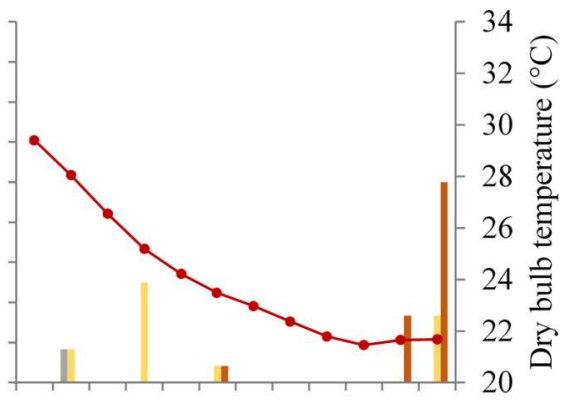

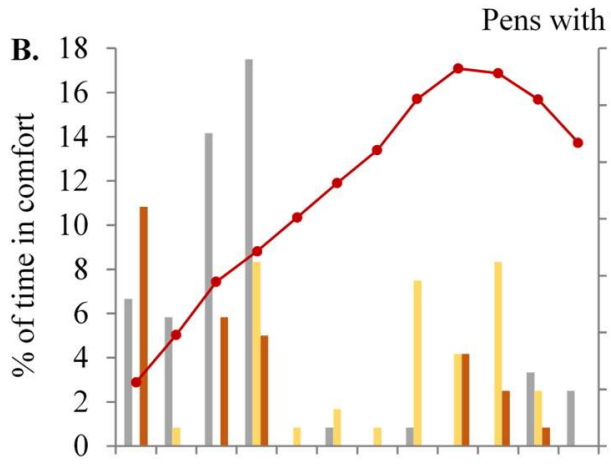

D.

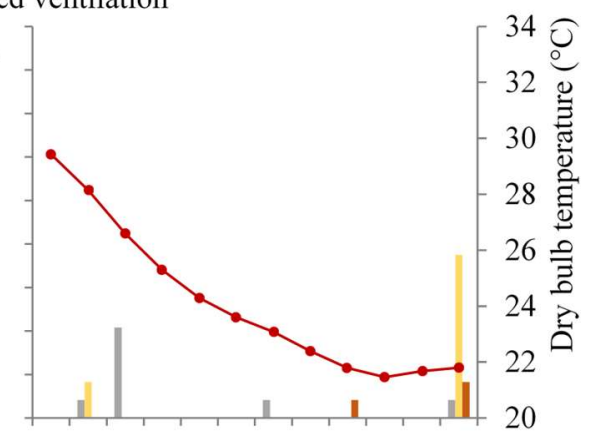

Pens with evaporative cooling
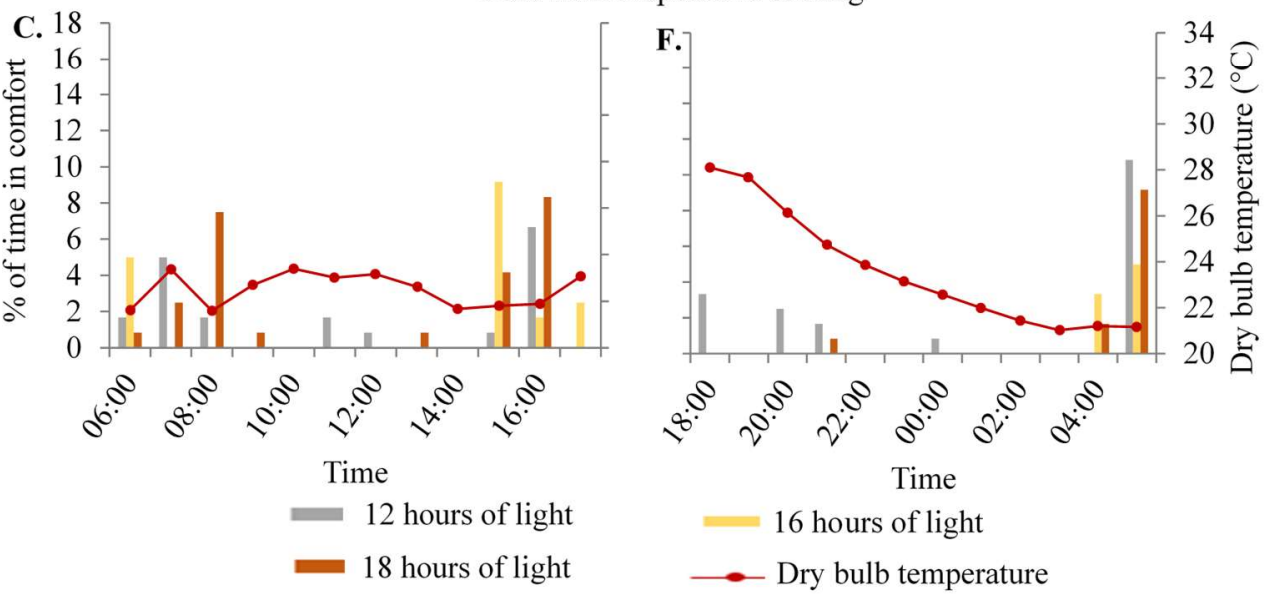

FIGURE 5. Percentage of time in "comfort" in the daytime (A, B and C) and nighttime (D, E and F) periods in pens with no climate control, with forced ventilation and with evaporative cooling, associated with the lighting programs of 12,16 and 18 hours of light $(\mathrm{p}<0.01)$.

This fact is also relevant from the animal welfare point of view, since the rearing environment must meet the concept of "five freedoms", which includes freedom to express their natural behavior, so thermal stress can harm or limit behaviors that express welfare.

It is also possible to observe that in pens with no climate control there was no record of activity at the times of 11 and $12 \mathrm{~h} 00$, which is probably a consequence of the effect of thermal stress. At night, the animals performed more "comfort" activities from 4 to $5 \mathrm{~h} 00$ (Figure 5D; E; F).
The lighting program that promoted the greatest manifestation of comfort behaviors was 18 hours of light. However, it is not possible to state that the lighting favored the activity of the animals, since the highest frequency occurred at $05 \mathrm{~h} 00$, time when supplementary lighting was turned off and natural lighting began.

The behavioral analysis showed that the animals housed in pens with no climate control spent more time lying down, which suggests a response to thermal stress, as well as lower feed intake. The lighting programs did not stimulate the increase in feed intake or in the frequency of the activities performed. 


\section{CONCLUSIONS}

The performance was better for animals subjected to evaporative cooling, and the supplementary lighting program of 18 hours promoted better feed conversion.

Pigs subjected to evaporative cooling showed higher frequency of comfort behaviors and higher frequency of ingestive activity, stimulated by better thermal conditions in the housing.

\section{ACKNOWLEDGMENTS}

The present study was conducted with support from the Coordination for the Improvement of Higher Education Personnel - Brazil (CAPES) - Finance Code 001.

\section{REFERENCES}

Amaral PIS, Ferreira RA, Pires AV, Fonseca LS, Gonçalves AS, Souza GHC (2014) Desempenho, comportamento e respostas fisiológicas de suínos em terminação submetidos a diferentes programas de luz. Journal of Animal Behaviour and Biometeorology 2(2):5459. DOI: http://dx.doi.org/10.14269/2318-1265.v02n02a05

Berton MP, Dourado RC, Lima FBF, Rodrigues ABB, Ferrari FB, Vieira LDC, Souza PA, Borba H (2015) Growing-finishing performance and carcass yield of pigs reared in a climate-controlled and uncontrolled environment. International Journal of Biometeoroly 59:955960. DOI: http://dx.doi.org/10.1007/s00484-014-0908-3

Carvalho LE, Oliveira SMP, Turco SHN (2004) Utilização da nebulização e ventilação forçada sobre o desempenho e a temperatura da pele de suínos na fase de terminação. Revista Brasileira de Zootecnia 33(6):1486-1491.

Ferreira RA, Fassani EJ, Ribeiro BPVB, Oliveira RF, Cantarelli VS, Abreu MLT (2015) Programas de luz para suínos em crescimento. Archives of Veterinary Science 20(3):65-70.

Ferreira RA, Fassani ÉJ, Rocha LF, Oliveira RF, Ribeiro BPVB, Abreu MLT, Cantarelli VS (2016) Desempenho e comportamento de suínos em fase de terminação submetidos a diferentes programas de luz. Revista Brasileira de Saúde e Produção Animal 17(2):272-279. DOI: http://dx.doi.org/10.1590/S151999402016000200014

Foppa L, Caldara FR, Machado SP, Moura R, Santos RKS, Nääs IA, Garcia RG (2014) Enriquecimento ambiental e comportamento de suínos: Brazilian Journal of Biosystems Engineering 8(1):01-07.

Kiefer C, Moura MS, Silva EA, Santos AP, Silva CM, Luz MF, Nantes CL (2010) Respostas de suínos em terminação mantidos em diferentes ambientes térmicos. Revista Brasileira de Saúde e Produção Animal 11(2):496-504.

Leal PM, Nããs IA (1992) Ambiência animal. In: Cortez LAB, Magalhães PSG. Introdução a engenharia agrícola. Unicamp, p121-135.

Maia APA, Sarubbi, J, Medeiros BBL, Moura DJ (2013) Enriquecimento ambiental como medida para o bem-estar positivo de suínos. Revista Eletrônica em Gestão, Educação e Tecnologia Ambiental 14(14):2862-2877. DOI: http://dx.doi.org/10.5902/2236117010746
Martelli G, Scalabrin M, Scipioni R, Sardi L (2005) The effects of the duration of the artificial photoperiod on the growth parameters and behaviour of heavy pigs. Veterinary research communications 29:367-369. DOI: http://dx.doi.org/10.1007/s1 1259-005-0367-8

Massari JM, Curi TMRC, Moura DJ, Medeiros BBL, Salgado DD (2015) Características comportamentais de suínos em crescimento e terminação em sistema "wean to finish”. Engenharia Agrícola 35(4):646-656. DOI: http://dx.doi.org/10.1590/1809-4430Eng.Agríc.v35n4p646-656/2015

Padilha ACM, Nodari M, Fernandes PM (2013) Análise do uso de água tratada na produção de suínos. Agropecuária Técnica 34(1):50-60.

Paiano D, Barbosa OR, Moreira I, Quadros ARB, Silva MAA, Oliveira CAL (2007) Comportamento de suínos alojados em baias de piso parcialmente ripado ou com lâmina d'água. Acta Scientiarum Animal Sciences 29(3):345-351.

Pandorfi H, Silva IJO (2005) Evaluation of the behavior of piglets in different heating systems using analysis of image and electronic identification. Agricultural Engineering International: the CIGR Ejournal 7(8):1-24

Reiners K, Hessel EF, Sieling S, Van Den Wegh E HF (2010) Influence of photoperiod on the behavior and performance of newly weaned pigs with a focus on time spent at the feeder, feed disappearance, and growth. Journal of Swine Health and Production 18(5):230-238.

Rostagno HS (2017) Tabelas brasileiras para aves e suínos. Composição de alimentos e exigências nutricionais. 4.ed. Viçosa, UFV, 4 ed. 488p.

Santos JHT, Tinoco IFF, Costa CA (2012) Avaliação diferentes sistemas de ventilação em terminação de suínos, para as condições do Centro-oeste brasileiro. Engenharia na agricultura 20(3):201-209.

Santos TC, Carvalho CCS, Silva GC, Diniz TA, Soares TE, Moreira, SJM, Cecon PR (2018) Influência do ambiente térmico no comportamento e desempenho zootécnico de suínos. Revista de Ciências Agroveterinárias 17(2):241-253. DOI:

http://dx.doi.org/10.5965/223811711722018241

SAS - Statistical Analysis System. SAS companion for the microsoft windows environment (2007) Version 8. SAS Institute, CD-Rom.

Silva TGF, Primo JTA, Moura MSB, Silva SMS, Morais JEF, Pereira PC, Souza CAA (2015) Soil water dynamics and evapotranspiration of forage cactus clones under rainfed conditions. Pesquisa Agropecuária Brasileira 50(7):515-525. DOI: http://dx.doi.org/10.1590/S0100204X2015000700001

Sousa Júnior VR, Abreu PG, Coldebella A, Lope LS, Monteiro GJMM, Sabino OLA (2011) Iluminação artificial no desempenho de leitões na fase de creche. Acta Scientiarum. Animal Sciences 33(4):403-408. DOI: http://dx.doi.org/10.4025/actascianimsci.v33i4.10828 